\title{
Developing generic skills for students via extra-curricular activities in Vietnamese universities: Practices and influential factors
}

\author{
Tran Le Huu Nghia \\ thnnghia@gmail.com \\ Melbourne Centre for the Study of Higher Education, University of Melbourne
}

\begin{abstract}
Developing generic skills (GS) for students has become central in many higher education curricula in recent times. However, there is still a lack of studies regarding how these skills are developed for students, especially in developing countries. Drawing from a PhD study, this paper reports the contribution of extra-curricular activities in developing GS for students in Vietnamese universities and analyses factors influencing the effectiveness of developing GS for students via these activities. A content analysis of relevant documents and 69 interviews with university leaders, academics and organisers of the Youth union and its associates (YUA) showed that extra-curricular activities were an integral component of a university's strategy for training students in GS. This was due to a lack of autonomy over the curriculum, which prevented most Vietnamese universities from adding skills subjects into the curriculum. Furthermore, the YUA also had a long-standing tradition of developing non-discipline-specific skills for students. The YUA were found to be successful in developing GS for students via extra-curricular activities; however, their operation was influenced by university leadership, student participation, external stakeholders' support, and the leadership of the YUA. The paper argues that extra-curricular activities were conducive to developing GS for students; therefore, they should be included in skills development programs in higher education.
\end{abstract}

Key words: higher education, generic skills, extra-curricular activities, Vietnam, the Youth Union

\section{Introduction}

Generic skills (GS) are defined as transferable, non-discipline specific skills that may be achieved through learning and can be applied in study, work, and life contexts (Tertiary Education Quality and Standards Agency, 2013). These skills are found to enhance university graduates' employability and lifelong learning abilities, help them cope with an unknown future, and enable them to act for the social good (Hager \& Holland, 2006). These skills include but are not limited to communication, teamwork, problem-solving, and critical thinking skills, creativity, resilience, among several others (Hager \& Holland, 2006).

Recently, initiatives related to GS implementation have been launched across the globe by international organisations and national governments (González \& Wagenaar, 2003; Hadgraft, Pearce, Edwards, Fraillon, \& Coates, 2012; Shattock, 2001). In many Western developed 
countries, higher education (HE) institutions have also begun to implement GS policy in their institutions using different concepts of GS, regardless of the consensus on developing GS to improve graduates' employability. For example, among many GS selected, Thai universities often focus on the development of ethical attributes for students to align with the Buddhist culture of the country (Chaisinthop, 2014; Thai Government, 2006). Another example includes the Danish Government call for their universities to invest in developing lifelong learning skills for students due to the aging population and the flexicurity economic model (Andersen, 2012; Danish Government, 2003). A study by Pitman and Broomhall (2009) also reveals differences in GS selected to develop for students between groups of Australian universities, which researchers linked to visions and missions of these groups of institutions. Universities were also found to implement GS policy at different scales as well as using different curriculum models and pedagogical practices (Al-Mahmood \& Gruba, 2007; Barrie, Hughes, Smith, \& Thomson, 2009; Pitman \& Broomhall, 2009). Some universities execute GS policy institutionwide (Fleming, Donovan, Beer, \& Clark, 2013) whereas others choose to implement it at a school or program level (O'Neill, 2009). Some universities embed GS that they have prioritised into each subject of a curriculum and employ student-centred pedagogies, including work integrated learning - to help students develop these skills via curriculum-based activities throughout their academic years (Al-Mahmood \& Gruba, 2007; Barrie et al., 2009; Stoner \& Milner, 2010). In contrast, some universities opt for developing stand-alone skills subjects to train students in GS independently from disciplinary contexts (Al-Mahmood \& Gruba, 2007; Barrie et al., 2009). Many also include extra or co-curricular activities to develop such skills for students (Barrie et al., 2009). In short, the literature suggests that GS have been implemented inconsistently across universities, and greatly depend on national and institutional contexts (Al-Mahmood \& Gruba, 2007; Barrie et al., 2009; Pitman \& Broomhall, 2009).

In Vietnam, a developing non-English speaking country in the East, the Ministry of Education and Training (MOET) has launched many initiatives in order to improve graduates' learning outcomes (Harman, Hayden, \& Pham, 2010). One of them was developing GS for students, which was scripted in the Guideline 2196/BGDĐT-GDĐH (MOET, 2010). However, there has not been a concrete definition for GS, even in the Guideline 2196/BGDĐT-GDĐH (MOET, 2010). Generally, these skills are understood as kỹ năng mềm (soft skills), kỹ năng sống (life skills), or kỹ năng làm việc (work skills). Among them, the concept that views GS as work skills seems to be dominantly adopted in many Vietnamese universities partly because the purpose of $\mathrm{HE}$ is to develop a highly quality workforce to serve the socio-economic targets of the country (Vietnamese National Congress, 2012). It is also adopted possibly because of the increasing demands for graduates with adequate work skills in the labour market (Bodewig, Badiani-Magnusson, \& Macdonald, 2014; Manpower Group, 2011). Since the Guideline was issued, there have not been any studies that specifically investigate how this GS policy is implemented in Vietnamese universities, especially ones examining the experiences and viewpoints of university leaders and academics, who are key agents of the implementation.

Therefore, a PhD study was conducted in late 2013 and early 2014 to investigate influential factors of GS implementation in six Vietnamese universities of different institutional contexts. One of the main findings of the study was that extra-curricular activities under the Youth Union and its associates (YUA) - a social-political organisation led by the Communist Party and installed in all universities and schools in Vietnam - were involved as an integral component to the institutional strategy for executing the MOET's GS policy. These activities were reported to have significantly contributed to developing GS for students. This finding differed from current practice in many Western universities that appraises the effectiveness of developing GS via curriculum-based activities, and often treats extra-curricular activities as secondary (Barrie et al., 2009). This paper will report types of extra-curricular activities that the YUA organised to develop GS for students in Vietnamese universities, analyse reasons why these activities were involved, and identify factors influencing the effectiveness of executing GS policy via these activities. The paper argues that extra-curricular activities have the potential

Nghia, T. (2017). Developing generic skills for students via extra-curricular activities in Vietnamese universities: Practices and influential factors. Journal of Teaching and Learning for Graduate Employability, 8(1), 22-39. 
to aid in the execution of GS policy; therefore, instead of disregarding them, university leaders should acknowledge, support and involve these activities in the institutional strategy for implementing GS policy, which will contribute to enhancing students' employment outcomes.

\section{Literature review}

\section{Context of GS implementation in Vietnamese HE}

The Vietnamese HE system possesses characteristics different from its counterparts in the West. It is characterised by a combination of Confucian morals, Western educational heritages and socialist ideologies (Harman et al., 2010; Pham \& Fry, 2002). The general aim of Vietnamese $\mathrm{HE}$ is to produce human resources with adequate skills and attributes to sustain the nation and integrate into the world market (Vietnamese National Congress, 2012). The HE system has been undertaking tremendous reforms in recent years, including developing GS for students, aiming to enhance the effectiveness of university operation and improve the quality of its graduates. However, numerous obstacles have challenged these reforms, including a lack of curriculum and institutional autonomy, inadequately qualified teachers, insufficient resources, and a lack of collaboration with industries, to name a few (Harman et al., 2010; Tran, 2009; Tran, 2015).

Developing GS, often conceptualised as work skills, for students has become an urgent mission for Vietnamese universities due to three factors. After the Doi Moi Policy, Vietnam has experienced a high economic growth rate for successive years and has aimed at becoming an industrialised and modernised country by 2020 (World Bank, 2008, 2017). Unfortunately, there has been a shortage of a skilled labour force that is capable of effectively performing work duties (Bodewig et al., 2014; Manpower Group, 2011; World Bank, 2008). To achieve socio-economic targets and meet the demands for skilled labour, Vietnamese universities have been expected to produce an adequate number of graduates with sufficient professional and work skills, which has place a huge pressure on them.

Secondly, Vietnam has been exposed to increasing regional and global competition in terms of education and economy. Upon becoming a member of the World Trade Organisation, Vietnam also signed the General Agreement on Trade Services, which allows foreign education providers to enter Vietnam to provide their services (Varghese, 2007). Along with that, it joined the ASEAN Economic Community at the end of 2015, which allowed free labour flow between member countries (The Association of Southeast Asian Nations, 2008). While joining the WTO and the ASEAN Economic Community could elevate Vietnam's competitiveness, it also exposes the country to intense competition in socio-economic, educational, cultural and political fields. In order to successfully compete in this community, and globally, the HE system is expected to produce competent graduates to adequately maintain the competitiveness of Vietnam in these markets.

Third, developing GS for students has become politically driven in Vietnam, both in primary, secondary and tertiary education. The Ministry of Education and Training has committed to improving the HE system in order to make it comparable and competitive with others in the world. The HE system has been undergoing unprecedented reforms since the early 2000 s (Harman et al., 2010). One of the central targets of the reforms is to increase the quantity and quality of university graduates, following the advice of the World Bank's consultation on planning for human resources to fill the need for socio-economic growth in the coming years (Pham, 2010). One of the initiatives that directly makes GS development an essential mission is the issue of the Guideline 2196/BGDĐT-GDĐH that formally mandated universities to develop GS for students (MOET, 2010). As such, on top of developing GS for students as an aspiration to addressing socio-economic demands, developing GS has become a compulsory initiative.

Nghia, T. (2017). Developing generic skills for students via extra-curricular activities in Vietnamese universities: Practices and influential factors. Journal of Teaching and Learning for Graduate Employability, 8(1), 22-39. 
In short, developing GS for students has become relevant and important in Vietnamese HE. However, there have been hardly any studies that specifically investigate how GS policy has been realised in the universities. This study, therefore, will focus on examining how GS are developed for Vietnamese university students using experiences and viewpoints of academics and university leaders, who are key agents in the process of developing these skills for students. The study will contribute to the existing literature by investigating GS implementation outside of Western university contexts.

\section{Extra-curricular and generic skills development}

Extra-curricular activities are often used to develop GS for students in Western universities in conjunction with curriculum-based activities (Barrie et al., 2009). As the name suggests, these activities are considered secondary to curriculum-based activities for developing GS for students. These may include service learning activities, volunteering programs, certain skillfocused clubs, serving in student committees or undertaking non-compulsory internships, travels or field trips (Barrie et al., 2009). Studies in this area consistently suggest that these extra-curricular activities offer students many informal learning opportunities which are conducive to the development of students' GS and greatly contribute to their employment outcomes (Chmielewski-Raimondo, McKeown, \& Brooks, 2016; Clark, Marsden, Whyatt, Thompson, \& Walker, 2015; Hager \& Holland, 2006; Lau, Hsu, Acosta, \& Hsu, 2014). For example, studying 28,768 Taiwanese business graduates, Lau et al. (2014) found that those who joined extra-curricular activities rated their communication, leadership, creativity, and selfpromotion skills higher than those who did not. A study by Clark et al. (2015) also revealed that in British alumni's opinions, extra-curricular activities helped develop their employability skills to a great extent, thus significantly contributing to helping them obtain their first job, and facilitating their work performance. Possibly for these benefits, extra-curricular activities have been used more often in order to develop GS for students in HE.

Different types of extra-curricular activities are found to influence the development of certain types of GS differently (Lau et al., 2014). First, service learning, a process in which students learn and develop through active participation in meaningful services that are needed by the community (Osman, 2011), provides good opportunities for students to develop their GS (for example, Kalles \& Ryan, 2015; Kearney, Perkins, \& Maakrun, 2014; Osman, 2011). By participating in this form of learning, students have opportunities to apply the already acquired knowledge into real-life situations, and develop several practical skills relevant for the context of that community. For example, in a study conducted in Malaysia, Osman (2011) found that students participating in provided service learning experiences were better able to understand their acquired knowledge and gain better communication skills in the multicultural context, as well as developing more effective collaborative working skills and higher perceptions of gender differences. The researcher also recognised a change in students' perceptions of actual education and meaningful learning experiences.

In addition, internships are beneficial for developing many GS for students (Barrie et al., 2009). Internships are often referred to as work-integrated learning, which is part of the curriculum and is often monitored by coordinators of a program or school. They can be categorised into the domain of extra-curricular activities in a sense that students can look for an unpaid position which may be relevant or irrelevant to their major to gain more work skills, experiences and connections with professionals (Barrie et al., 2009). Internships have been reported to help students develop a variety of GS, consolidate their specialised knowledge and skills and increase their employment opportunities (Shoenfelt, Stone, \& Kottke, 2013; Tse, 2010). However, except for work placement organised by universities, there are not enough internship opportunities, as extra-curricular activities, available for all students to participate (Barrie et al., 2009); thus, they must compete for such precious opportunities.

Nghia, T. (2017). Developing generic skills for students via extra-curricular activities in Vietnamese universities: Practices and influential factors. Journal of Teaching and Learning for Graduate Employability, 8(1), 22-39. 
Furthermore, travel and field trips are also reported to be conducive to developing GS for students (Chmielewski-Raimondo et al., 2016; Falk, Ballantyne, Packer, \& Benckendorff, 2012; Scarinci \& Pearce, 2012). For example, Scarinci and Pearce (2012) studied 326 undergraduate business students at Northwood University (Florida, USA) and found that travels helped students improve 18 GS moderately to greatly. The skills that improved the most were independence, being open-minded, adaptability, feeling comfortable around all types of people, being understanding and overall awareness. However, these activities are costly and need external stakeholders' support; thus, it is not often organised, especially in developing countries and by those who self-fund their higher education studies.

However, organising extra-curricular activities has faced many barriers. The first challenge is associated with student participation. As it is treated as extra-curricular, many students may disregard the importance of such activities when compared with specialised knowledge taught in class (Al-Ansari et al., 2016; Tran, 2015). The second challenge is that some types of extracurricular activities - such as being a research assistant or intern, or serving in a student committee - are unable to involve a large number of students (Barrie et al., 2009). Next, in most extra-curricular activities, students appear to only play the role of observers, which hinders them from developing leadership skills or organisational skills. Finally, as most extracurricular activities are linked to local communities, the support of external stakeholders, such as local people, industries or authorities are essential. Without their support, extra-curricular activities may only occur on campus, which will hinder the development of GS in real-life contexts.

In the case of Vietnam, extra-curricular activities have been coordinated by the Youth Union, which is a social-political organisation founded by Ho Chi Minh and led by the Labour Party, the only political party in Vietnam currently. Information on the website of the Youth Union (Ho Chi Minh Communist Youth Union, 2015) declares its three functions as below:

- Contributing to building the Party, inheriting and sustaining the legacy of the Party and Ho Chi Minh;

- Creating an environment for young people to study and develop their personalities, competence of a worker suitable for the society's; and

- Being a representative who cares and protects the legal rights of young people.

In Vietnamese universities, the primary duty of the Youth Union is to provide political education to students. However, it also extends to work with other clubs that develop students' learning skills, nurturing their talents in music and fine arts, or with agencies that assist students with their career, and with student associations to conduct social engagement activities. For example, they have organised the Green Summer Campaign (Chiến dịch Mùa Hè Xanh) for students to go to rural areas to teach poor children or help disadvantaged people, or they transfer knowledge and technologies to farmers. Recently, the organisations have been involved in teaching students concrete skills that immediately enhance students' employment outcomes (Tran, 2015). In some universities, the YUA also links students with local employers and industries through career fairs or career consultation services. Although they are categorised as extra-curricular activities, student participation in those activities are usually recorded and assessed against concrete criteria at the end of each semester to generate the so-called điểm rèn luyện, or self-improvement score. It is not added into students' academic achievements, but is used as a reference when granting scholarships. Still, students' achievements in YUA activities are often beneficial for students when they look for employment, especially in public services and organisations.

The roles of the YUA extra-curricular activities in Vietnamese universities have not been adequately researched and documented. The reason why the YUA extra-curricular activities were involved, how effectively they could contribute to executing GS policy, and which factors influenced the effectiveness of developing GS for students via these activities should be

Nghia, T. (2017). Developing generic skills for students via extra-curricular activities in Vietnamese universities: Practices and influential factors. Journal of Teaching and Learning for Graduate Employability, 8(1), 22-39. 
examined adequately. By doing so, more insights into practices for GS implementation in HE contexts would be produced, adding more options for universities to choose from when executing GS policy.

\section{The study}

The $\mathrm{PhD}$ study was conducted as a qualitative multiple case study, which provides an opportunity to investigate the implementation of GS in its real-life context and to compare the implementation across the cases to identify similarities and differences (Yin, 2009). The study received ethics approval from the University of Melbourne in 2013.

The universities were selected based on the maximum variation sampling principle, which allowed the researcher to achieve representativeness by looking for universities of a wide range of extremes (Merriam, 2009). In total, three public and three non-public universities of different institutional contexts were recruited for this study (Table 1). To ensure feasibility, this study was conducted in the south of Vietnam. To preserve the distinctive characteristics of GS in a discipline (Jones, 2010), this study focused on investigating the implementation of GS solely in the Business Administration program, rather than across disciplines offered by the selected universities. Focusing on one program allowed the researcher to analyse the implementation of that program across levels of a university organisation structure and compare the implementation across the universities more reasonably. The Business Administration program was chosen for two reasons: (1) it is the most popular program found across the universities in Vietnam, and (2) there is more evidence of GS implementation in the Economics Schools than others.

The participants in each selected university were recruited using a snowball sampling technique (Browne, 2005), which allowed the researcher to approach potential participants based on the recommendation of another participant. The researcher first searched profiles of university leaders on the university website and contacted the one in charge of academic affairs to request permission to conduct the study in their institution, as well as to obtain an interview. That university leader was then asked to nominate leaders of the School of Business Administration (or an equivalent title) that were involved in the implementation, to be interviewed. After interviewing these school leaders, the researcher then asked them to nominate teachers who would be interviewed about how GS policy was put into practice at the subject level. The researcher also sent emails to the YUA leaders so that they could appoint an organiser to attend the interview, in most cases, this would be the leader of the Youth Union. This technique helped ensure that the researcher interviewed key informants involved in GS implementation in their institution. In total, 69 university leaders, school leaders, disciplinary teachers and skills teachers, as well as the YUA leaders and staff members (hereafter, YUA organisers) were recruited (Table 1). Students were not involved in this study because it focused specifically on analysing university leaders', university staff members' and academics' viewpoints. 
Table 1. Summary of Universities and Participants

\begin{tabular}{|c|c|c|}
\hline Name & Institutional context & Participants \\
\hline $\begin{array}{l}\text { University A } \\
\text { (public) }\end{array}$ & $\begin{array}{l}\text { Located in a regional city, University } A \text { is governed by } \\
\text { the MOET in terms of academic affairs, and by both } \\
\text { the MOET and the local authority in terms of finance } \\
\text { and administration. This institutional context is typical } \\
\text { for most public universities in the system. }\end{array}$ & $\begin{array}{l}\text { - } 4 \text { leaders } \\
\text { - } 7 \text { teachers } \\
\text { - } 2 \text { YUA } \\
\text { organisers }\end{array}$ \\
\hline $\begin{array}{l}\text { University B } \\
\text { (public) }\end{array}$ & $\begin{array}{l}\text { Located in a metropolitan city, University B is } \\
\text { considered one of the } 14 \text { key universities in Vietnam } \\
\text { at the time of research. It was waiting for autonomy in } \\
\text { curriculum design and finance management to be } \\
\text { enacted in } 2015 \text {. The context of a prestigious } \\
\text { university without curriculum autonomy makes it a } \\
\text { special case to include in this study. }\end{array}$ & $\begin{array}{l}\text { - } 4 \text { leaders } \\
\text { - } 8 \text { teachers } \\
\text { - } 1 \text { YUA } \\
\text { organiser }\end{array}$ \\
\hline $\begin{array}{l}\text { University C } \\
\text { (public) }\end{array}$ & $\begin{array}{l}\text { Located in an average-sized city, University C is } \\
\text { considered one of the leading universities of the eight } \\
\text { socio-economic regions in Vietnam. It is directly } \\
\text { governed by the MOET in terms of academic affairs, } \\
\text { funding and administration. In recent years, it has } \\
\text { become well known for innovations in pedagogy and } \\
\text { management practices. }\end{array}$ & $\begin{array}{l}\text { - } 3 \text { leaders } \\
\text { - } 9 \text { teachers } \\
\text { - } 1 \text { YUA } \\
\text { organiser }\end{array}$ \\
\hline $\begin{array}{l}\text { University D } \\
\text { (private) }\end{array}$ & $\begin{array}{l}\text { Located in a metropolitan city, University D was } \\
\text { upgraded from a semi-public vocational college in a } \\
\text { metropolitan city. It is among } 37 \text { non-public } \\
\text { universities that was established or upgraded after the } \\
\text { HERA was launched in } 2005 \text {. It is supervised by the } \\
\text { MOET, but with curriculum autonomy. This curriculum } \\
\text { autonomy and vocational education tradition make it } \\
\text { a special case study. }\end{array}$ & $\begin{array}{l}\text { - } 4 \text { leaders } \\
\text { - } 5 \text { teachers } \\
\text { - } 1 \text { YUA } \\
\text { organiser }\end{array}$ \\
\hline $\begin{array}{l}\text { University E } \\
\text { (private) }\end{array}$ & $\begin{array}{l}\text { Located in a regional city, University E is among } 37 \\
\text { non-public universities that was established or } \\
\text { upgraded after the HERA was approved by the MOET } \\
\text { in 2005. This university reports to the MOET mostly in } \\
\text { terms of academic affairs. It does not have curriculum } \\
\text { autonomy. This university represents newly } \\
\text { established private universities in Vietnam. }\end{array}$ & $\begin{array}{l}\text { - } 3 \text { leaders } \\
\text { - } 6 \text { teachers } \\
\text { - } 1 \text { YUA } \\
\text { organiser }\end{array}$ \\
\hline $\begin{array}{l}\text { University F } \\
\text { (private) }\end{array}$ & $\begin{array}{l}\text { Located in a metropolitan city, University } \mathrm{F} \text { is one of } \\
\text { the first } 17 \text { non-public universities in Vietnam that } \\
\text { were established in the 1990s. The university is } \\
\text { supervised by the MOET primarily in terms of } \\
\text { academic affairs. It represents the longest- } \\
\text { established private universities in Vietnam. }\end{array}$ & $\begin{array}{l}\text { - } 3 \text { leaders } \\
\text { - } 6 \text { teachers } \\
\text { - } 1 \text { YUA } \\
\text { organiser }\end{array}$ \\
\hline
\end{tabular}

Semi-structured interviews (Horton, Macve, \& Struyven, 2004) were used to collect data from the participants. In the interviews, participants were asked about factors influencing the implementation of GS policy in their institution, based on their experience. The interviews focused on three aspects of the implementation: (a) leadership and management issues, (b) curriculum-based GS development activities, and (c) extra-curricular activities that nurtured 
students' GS development. All interviews were recorded and transcribed verbatim for the analysis. In addition, documents that were available on university websites or provided by participants were collected. Examples of these documents were statements of learning outcomes, minutes and decisions made by university and school leaders on issues related to curriculum and learning outcomes, samples of lessons plan and assessment tasks that teachers used to teach and assess GS.

A qualitative content analysis was employed to analyse the data (Elo \& Kyngäs, 2008). This approach not only allowed the researcher to draw key points of GS implementation but also interpret why they occur (Kohlbacher, 2006), which fits the purpose of this study. For the purpose of this article, on a case by case basis, data were coded and put into three categories: (i) reasons that Vietnamese universities involved the YUA extra-curricular activities in developing GS for students, (ii) what extra-curricular activities were organised to train students in GS, and (iii) factors influencing the effectiveness developing students' GS via the YUA extracurricular activities. The codes were subsequently compared across the cases to find similarities and differences. This step also involved evidence-based interpretation of factors influencing the roles and contributions of the YUA extra-curricular activities. Finally, the results emerging from the analysis were organised into the final report.

\section{Findings}

The analysis showed that regardless of the differences in GS they selected to train students in, the six universities shared the same concept when executing the MOET's GS policy: developing work-readiness skills for students. Examples of skills they treated as GS within the adopted concept were creativity, communication, presentation, teamwork, problem-solving, CV writing and job interview skills. In line with the Guideline 2196/BGDĐT-GDĐH (MOET, 2010), they also treated English and computer skills as GS. The universities commonly translated the concept into practice in two ways.

- Via curriculum-based activities, they added some skills subjects, which were coordinated by skills teachers, to train students in work-related GS. In specialised subjects of a discipline, they either explicitly required or only encouraged disciplinary teachers to develop GS for students.

- Via extra-curricular activities, under the YUA, they invited skills experts, successful business people or employers to inspire students, train them in practical work skills such as job interviews and CV writing. The YUA also collaborate with external stakeholders to organise community engagement activities, field trips or charity work, through which students could also develop a myriad of GS.

As such, extra-curricular activities were included in the institutional strategy for executing GS policy in Vietnamese universities. However, the contribution of this type of informal learning appeared to vary between the six universities.

\section{University $A$}

The university and school leaders suggested that the YUA extra-curricular activities were involved in GS implementation because the MOET's regulations of 120-140 credits for undergraduate programs restricted them from adding skills subjects into the curriculum, and because the YUA had experience in training students in social skills via different types of extracurricular activities.

The YUA organisers stated that they had successfully organised diverse extra-curricular activities to (i) support the transition of first year students into the university, and (ii) help final year students succeed when seeking employment. Together with the YUA organisers, participants consistently reported that students could join the YUA skills classes, career 
consultation, career fairs, and social engagement activities with the support of skills experts, employers and successful business people. The YUA organisers commented that although the YUA activities were voluntary, student participation rates were high, commenting that students learned eagerly and asked many questions in their skills classes.

The YUA organisers acknowledged the support of university leaders - mostly in administrative work-as a significant factor in their success, while a lack of funding and connections with people in industries limited their work. They explained that being a small university in a regional city, they did not receive any donations from alumni, employers or enterprises, aside from financial aid from an international organisation to teach skills for students from disadvantaged backgrounds. They revealed that the university did not have many resources for extra-curricular activities, as much of it was allocated for reforming academic and administrative practices simultaneously occurring in the institution.

\section{University $B$}

The university leaders suggested that they intentionally delayed GS implementation via curriculum-based activities until 2015, when they would have autonomy in curriculum and finance management to conduct a comprehensive institutional reform. Therefore, at the time of research, the YUA extra-curricular activities were the main channel through which students could develop GS in the university. This is not surprising given that the YUA were experienced in organising extra-curricular activities, as was confirmed by most participants from this university.

The participants consistently reported many types of activities that the YUA had been organising to develop GS for students, such as career consultation, seminars on work skills, CV writing and job interview skills, charity work or field trips to local businesses. The participants agreed that students who joined the YUA extra-curricular activities appeared to possess better GS than those who did not.

However, in participants' views, despite a high rate of student participation in the YUA activities, many of them appeared to participate only for the self-improvement score, which influenced their scholarship and probably future employment opportunities. The YUA organiser also pointed out that students and staff members in the university still considered the YUA activities as play rather than learning, which he saw as the biggest obstacle for the YUA to conduct GS training for students. Fortunately, the YUA organiser, university leaders and three teachers reported that extensive connections with industries facilitated the YUA work regarding developing work-readiness skills for students in terms of providing financial support, skills experts, and field trips.

\section{University $C$}

Like most of the cases in this study, the university and school leaders interviewed suggested that they involved the YUA extra-curricular activities in GS implementation because of the MOET's restriction of the credit number for undergraduate programs, which made it difficult to add skills subjects into the curriculum. Moreover, based on the YUA's effective operation, university leaders decided to let the YUA to coordinate at least compulsory skills subjects to all students in the university, not only voluntary activities as in the other five universities.

The YUA organiser suggested three main objectives of the YUA extra-curricular activities: (i) developing students' confidence, (ii) enhancing their abilities for social engagement, and (iii) improving their employment outcomes. He named many activities that would develop GS for students, such as career consultation, skills classes, career fairs, arts clubs, charity organisations, and community engagement activities. All participants in this case suggested that extra-curricular activities helped improve GS for students to a great extent.

Nghia, T. (2017). Developing generic skills for students via extra-curricular activities in Vietnamese universities: Practices and influential factors. Journal of Teaching and Learning for Graduate Employability, 8(1), 22-39. 
The YUA leader suggested that neighbouring provincial authorities and student associations supported their community engagement activities greatly in terms of finance and administrative work. He also mentioned that a shortage of funding from the university, and lack of connections with employers and skills experts in industries, limited work skills training activities. In a finding similar to that in University B, participants recognised a high rate of student participation in the YUA activities; however, participants ascribed it to students' attempts to get self-improvement scores rather than to improve their skills.

\section{University $D$}

Participants from this university proudly reported that they had successfully developed GS for students via curriculum-based activities, which they attributed to university leadership, curriculum autonomy, and connections with industries. Nevertheless, this university involved the YUA extra-curricular activities as an additional channel for students to develop GS in reallife contexts, as suggested by a university leader.

Unlike the other five cases, the YUA extra-curricular activities played the role of an additional channel through which students could further improve their GS. However, students themselves selected, designed and organised extra-curricular activities to train themselves as well as their peers in the desired skills with minimal direction from the YUA leaders. The interviewed YUA organiser reported that students had established more than 20 clubs to develop technical and generic skills for themselves, plus charity organisations and talent clubs.

The YUA organiser suggested that extensive connections with industries and proactive students enhanced the development of GS for students via extra-curricular activities. However, he recognised that students did not know how to apply for funds from the university or raise funds from external stakeholders, although these were available for them.

\section{University $E$}

The YUA organiser and university leaders suggested that the MOET's regulation of credit number made university and school leaders unable to add all skills subjects into the curriculum as they wished; therefore, the YUA extra-curricular activities were used as a means for students to develop their GS in addition to skills subjects the university had attempted to insert into the curriculum.

The YUA organiser stated that the main purpose of the YUA work was (i) creating an environment for students to apply GS that they had learned in the class, and (ii) facilitating students' transitions from the university to the workplace. He reported that apart from developing political attributes, the YUA usually organised meetings with successful business people, career consultations, career fairs, and contests on disciplinary knowledge, sports, and arts.

The YUA organiser and all leaders suggested that participation of young academics and university staff members encouraged students to participate in the YUA activities. In the YUA organiser's opinion, a lack of personnel was a challenge. He illustrated this with the example of the suspension of the Green Summer Campaign, which was due to some students committing offences due to a lack of available staff members who would monitor students during the campaign. He also reported that a lack of funding from the university, due to university leaders allocating resources on building teacher capacity and facilities, and a shortage of donations from external stakeholders, due to being a small, newly established regional university, caused them to restrict their extra-curricular activities within the campus. 
In the School of Business Administration of University $F$, the Dean refused to add skills subjects into the curriculum, as indicated by all disciplinary teachers in this case. This made the YUA extra-curricular activities the primary channel for students to develop GS in this school.

The YUA organiser listed many extra-curricular activities they had organised, such as skills classes, career consultation, career fairs, social engagement activities and recreational activities that promoted competitiveness, collaboration and creativity on top of their primary role of training political qualities. To him, most of the extra-curricular activities were aimed to equip students with work-readiness skills.

The YUA organiser suggested that the support of university leaders, in terms of resources and administrative work, and assistance of young academics in organising extra-curricular activities, facilitated their work. More than half of the participants commented that existing relationships with business people and alumni benefited the YUA with the development of work-readiness skills for students via extra-curricular activities. However, the YUA organiser and three disciplinary teachers observed that many students only participated for the selfimprovement scores, which reduced the effectiveness of developing GS for students via the YUA activities.

\section{Discussion and conclusion}

The intention of this study was to examine how extra-curricular activities could help develop GS for students, analyse reasons why they were involved, and identify factors influencing the effectiveness of executing GS policy via this channel. Each issue will be discussed in more depth in the following sections.

The interviews with the participants of the six universities revealed that the YUA conducted five types of extra-curricular activities to develop GS for their students:

- Training political qualities. The YUA organisers stated that it was their conventional duty and that acquiring these political qualities would enable students to function more effectively in a socialist society. Some examples of these qualities are a stable communism political stance, loyalty to the Vietnamese Communist Party, and understanding work conventions and practices in public organisations.

- Coordinated skills classes. The YUA regularly invited GS experts, both internal and external, to teach important work-readiness skills such as communication skills, job interview skills, CV writing, presentation skills, teamwork and career planning skills.

- Career consultation. The YUA in the universities provided a career consultation service where students could come and request advice about their career paths. However, some of the participants noted that not many students used this service, suggesting that students were unaware of it.

- Linking students with employers. Career fairs were organised in four universities so that students could meet potential employers, participate in mock job interviews, and attend workshops in CV writing and job interviews.

- Social engagement activities. Diverse activities were organised to help students integrate into social programs such as the Green Summer Campaign, caring for orphans and the elderly, HIV propaganda, environment protection projects, to name a few. Information on university websites also reveals initiatives that helped students acquire cross-cultural competence, including cultural exchanges between Vietnamese, Thai and Malaysian students in University C, or pairing Vietnamese and foreign students in exchange semesters in University D. 
Unlike the existing literature (Barrie et al., 2009; Chmielewski-Raimondo et al., 2016; Falk et al., 2012; Scarinci \& Pearce, 2012), internships and field trips were not organised by the YUA, but they were included as capstone and compulsory subjects in many programs offered by Vietnamese universities. Together with treating English and computer skills as GS, the placing of internships and field trips within the domain of curriculum-based activity, confirms that GS are conceptualised differently between HE contexts (Pitman \& Broomhall, 2009).

The analysis suggested two main reasons why the YUA extra-curricular activities were involved. Firstly, curriculum and pedagogical issues prevented the use of curriculum-based activities to develop GS for students. In the literature, many universities choose to embed GS into subjects in the curricula. However, this strategy depends heavily on the engagement and collaboration of all teachers as well as their capacity to use effective pedagogies to impart disciplinary knowledge and skills as well as GS to students. This strategy appears unfeasible for many Vietnamese universities due to a lack of teachers' capacity and their inertia in using traditional teaching and learning methods. It was likely this was the reason that Vietnamese universities chose to add skills subjects into curricula, as this strategy made GS implementation more explicit to stakeholders, and only required the engagement of skilled teachers or experts. Other teachers in the universities were required or encouraged to teach GS dependent on the policy of each institution. Unfortunately, the MOET's regulation of 120140 credits per undergraduate program prevented five universities from adding more than two skills subjects that trained students in communication, teamwork, and problem-solving skills among others. Therefore, the YUA extra-curricular activities were used to offer students more opportunities to develop GS. Although University D could develop GS for students via curriculum-based activities due to having curriculum autonomy, extra-curricular activities were used to create more opportunities for students to practice the GS they learned in class. Secondly, the YUA had a long-standing tradition of training students in social engagement activities. Therefore, it was relevant for them to continue and expand their work regarding training students in GS, not just in social engagement skills. Perhaps, without these two concurrently existing conditions, Vietnamese universities would have added many skills subjects into the curricula, or with adequate experience, integrated the selected GS into disciplinary subjects, and continued to treat extra-curricular activities as an adjunct part of students' campus life, as seen in Western universities (Barrie et al., 2009). Thus, the involvement of the YUA extra-curricular activities in training GS for students incidentally elevated the importance of the so-called 'extra-curricular activities' in Vietnamese universities.

Regardless of multiple activities the YUA organised to train students in GS, the role of these activities in the institutional GS implementation strategy varied between the universities. At the time of research, along with difficulty caused by the MOET's regulation of credits, there were many priorities or institutional reforms simultaneously taking place (Harman et al., 2010); therefore, the YUA's extra-curricular activities were the main channel through which GS policy was executed in five universities. In University D, the YUA extra-curricular activities were an additional channel for implementing GS policy. Aside from being a principal or additional channel in executing GS policy, it was evident in this study that the YUA extra-curricular activities contributed a great deal to the development of students' GS. Most participants agreed that students who participated in the YUA activities were more 'active' and 'dynamic', self-regulated their learning more effectively, as well as obtaining employment upon graduate earlier than their peers. Although students' perspectives were not investigated in this study, participants' experiences suggested that extra-curricular activities were conducive to developing GS in students, as found in recent studies (Kalles \& Ryan, 2015; Kearney et al., 2014; Osman, 2011). Thus, with such contributions to the development of students' GS, extracurricular activities should be involved as an inherent part of the institutional strategies for training students in these skills. 
Regarding factors influencing the effectiveness of the YUA extra-curricular activities, this appeared to be firstly influenced by institutional leadership. Included as an integral part of the institutional GS implementation strategy, the YUA extra-curricular activities had to be organised in line with the institutional concept for executing GS policy. In this study, although there were slight differences in which skills each university selected, the main concept of the implementation was developing work-readiness skills, which is consistent with the purpose of the HE system (Vietnamese National Congress, 2012); therefore, YUA extra-curricular activities were also oriented in this direction, as evidenced earlier. Also, institutional leadership defined the YUA extra-curricular activities as the principal or additional channel through which GS implementation was executed. This determined the extent to which the YUA extracurricular activities could contribute to developing students' GS during their time at the university. Likewise, how university leaders communicated the role of the YUA extra-curricular activities to stakeholders also would either facilitate or hinder their work. The analysis showed that in most of the case studies, students, teachers and other stakeholders were not adequately informed with clarity on the role. Therefore, the YUA extra-curricular activities were still disregarded and the importance of this style of informal learning continued to be underestimated. These findings indicate that institutional leadership must be effectively exercised in order to change stakeholders' views of and engagement with developing GS via extra-curricular activities.

Secondly, the effectiveness of the YUA extra-curricular activities seemed to depend on students' participation. Many participants across the six universities observed that students joined in the YUA activities enthusiastically and associated participation with progress in GS or employment outcomes. At the same time, the participants also observed that many students only participated in these activities for the self-improvement score that would enhance their chance of getting a scholarship, which is consistent with a finding from Tran (2015) who interviewed Vietnamese students and found that they often participated in GS-development activities superficially. Therefore, it is imperative that universities inform stakeholders of the role and the benefits of participating in the YUA's extra-curricular activities, should they use these activities as a channel to develop GS for students.

Thirdly, an extensive connection with external stakeholders appears to be significant for the YUA to organise extra-curricular activities. This study showed that the majority of extracurricular activities were organised with the support of external stakeholders' in terms of personnel or donation. Due to the simultaneous occurrence of institutional reforms and GS policy implementation (Harman et al., 2010), the six universities appeared to have allocated insufficient resources for the YUA activities. All YUA organisers reported to have used the small grant for prioritised activities from the university, and had looked for other sources of funding from external stakeholders. In this respect, the YUA of well-known universities, which also had an extensive network with industries, seemed to receive more personnel and financial support from employers and successful alumni, as demonstrated in University B, and from local authorities, as shown in University C. In contrast, this study also documented that the YUA at University $E$ struggled with organising extra-curricular and social engagement activities mostly due to a lack of funding from the university and almost no donations from external stakeholders. This case is consistent with previous studies that found many Vietnamese universities have not adequately collaborated with external stakeholders in their teaching, training and research activities (Tran, 2009; Tran, 2015). All of these findings suggest that universities should endeavour to develop networks with external stakeholders in order to facilitate the use of extra-curricular activities for developing GS for students.

Fourth, the YUA leaders influenced GS implementation via extra-curricular activities. Most often, they decided which GS development activities would be organised, which skills experts would be invited, and the location that social engagement activities would take place. All of these were associated with their perception of the relevance of certain kinds of GS for students in the university, their experience in operating the YUA, and their networking with external

Nghia, T. (2017). Developing generic skills for students via extra-curricular activities in Vietnamese universities: Practices and influential factors. Journal of Teaching and Learning for Graduate Employability, 8(1), 22-39. 
stakeholders. Therefore, involving YUA leaders in the process of conceptualising the implementation, developing their leadership skills and supporting them in forging relationships with external stakeholders are essential for the overall success of GS implementation.

\section{Limitations and Conclusion}

This study relied on perspectives of university leaders, academics and the YUA leaders rather than the perspectives of students and graduates. Therefore, the usefulness of extra-curricular activities in developing GS for students in HE should be interpreted cautiously. Future studies should include the voices of all stakeholders in order to explore how they view the importance of extra-curricular activities and confirm whether extra-curricular activities are conducive to the development of students' GS and to what extent their GS could develop via such activities.

In short, this study evidenced that extra-curricular activities could be used to successfully implement GS policy in HE. Diverse in their forms and interesting in nature, these activities are not always restricted by factors such as teacher qualifications, time, and venue. Therefore, they should be included as an inherent component of the institutional strategy for executing GS policy, rather than an adjunct element as seen in many universities now. However, in order to effectively use these types of activities for the implementation, a number of issues need due attention. As extra-curricular activities are often treated as 'extra' and disregarded by students and other stakeholders, university leaders must communicate to students the importance and the role of these activities in developing GS, so that students can engage with participating in this type of informal learning and other stakeholders can give support when necessary. They should also allocate adequate resources for extra-curricular activities proportional to the contribution they could bring to student skills development programs in higher education. Additionally, forging relationships with external stakeholders such as employers, skills experts, alumni, and local authorities is pivotal to developing GS for students via this channel because these stakeholders would create more opportunities, provide personnel or resources for learning via extra-curricular activities. All of these measures would elevate the roles of extra-curricular activities in $\mathrm{HE}$, and they would no longer be inferior to other academic activities in developing GS for students. 


\section{Acknowledgements}

This study was funded by the Endeavour Scholarship and Fellowship Program, Australian Government. The author acknowledges thoughtful comments and advice on earlier drafts from Associate Professor Sophie Arkoudis, Doctor Ryan Naylor and the anonymous reviewers. I am grateful to all of the participants and those who have supported me with the project.

Nghia, T. (2017). Developing generic skills for students via extra-curricular activities in Vietnamese universities: Practices and influential factors. Journal of Teaching and Learning for Graduate Employability, 8(1), 22-39. 


\section{References}

Al-Ansari, A., Al-Harbi, F., AbdelAziz, W., AbdelSalam, M., El Tantawi, M. M., \& EIRefae, I. (2016). Factors affecting student participation in extra-curricular activities: A comparison between two Middle Eastern dental schools. The Saudi Dental Journal, 28(1), 36-43.

Al-Mahmood, R., \& Gruba, P. (2007). Approaches to the implementation of generic graduate attributes in Australian ICT undergraduate education. Computer Science Education, 17(3), 171-185. doi:10.1080/08993400701538054

Andersen, T. (2012). A flexicurity labour market in the great recession: The case of Denmark. De Economist, 160(2), 117-140. doi:10.1007/s10645-011-9181-6

Barrie, S., Hughes, C., Smith, C., \& Thomson, K. (2009). National GAP issues papers. Retrieved from http://www.itl.usyd.edu.au/projects/nationalgap/resources/GAPpdfs/NationalGAP_issue s_Papers.pdf

Bodewig, C., Badiani-Magnusson, R., \& Macdonald, K. (2014). Skilling up Vietnam: Preparing the workforce for a modern market economy: World Bank Publications.

Browne, K. (2005). Snowball sampling: Using social networks to research non-heterosexual women. International Journal of Social Research Methodology, 8(1), 47-60. doi:10.1080/1364557032000081663

Chaisinthop, N. (2014). Volunteering, Dana, and the cultivation of 'good people' in Thailand. Anthropological Forum, 24(4), 396-411. doi:10.1080/00664677.2014.965129

Chmielewski-Raimondo, D. A., McKeown, W., \& Brooks, A. (2016). The field as our classroom: Applications in a business-related setting. Journal of Accounting Education, 34, 41-58. doi:http://dx.doi.org/10.1016/j.jaccedu.2015.11.002

Clark, G., Marsden, R., Whyatt, J. D., Thompson, L., \& Walker, M. (2015). 'It's Everything Else You Do...': Alumni views on extracurricular activities and employability. Active Learning in Higher Education, 16(2), 133-147.

Danish Government. (2003). Qualifications framework for Danish higher education. Retrieved from http://ufm.dk/en/education-and-institutions/recognition-andtransparency/transparency-tools/qualifications-frameworks/other-qualificationsframeworks/danish-qf-for-higher-education/qf_dk_he_261009.pdf

Elo, S., \& Kyngäs, H. (2008). The qualitative content analysis process. Journal of advanced nursing, 62(1), 107-115. doi:10.1111/j.1365-2648.2007.04569.x

Falk, J. H., Ballantyne, R., Packer, J., \& Benckendorff, P. (2012). Travel and learning: A neglected tourism research area. Annals of Tourism Research, 39(2), 908-927. doi:10.1016/j.annals.2011.11.016

Fleming, J., Donovan, R., Beer, C., \& Clark, D. (2013). A whole of university approach to embedding graduate attributes: A reflection. In J. Willems, B. Tynan, \& R. James (Eds.), Global challenges and perspectives in blended and distance learning (pp. 246-257). Hershey, PA: Information Science Reference.

González, J., \& Wagenaar, R. (2003). Tuning educational structures in Europe. Bilbao: University of Deusto

Hadgraft, R., Pearce, J., Edwards, D., Fraillon, J., \& Coates, H. (2012). Assessing higher education learning outcomes in civil engineering: The OECD AHELO feasibility study. Paper presented at the Profession of Engineering Education: Advancing Teaching, Research and Careers, Melbourne, 2012. Melbourne: Australasian Association for Engineering Education. 
Hager, P., \& Holland, S. (2006). Graduate attributes, learning and employability. Dordrecht, Netherlands: Springer.

Harman, G., Hayden, M., \& Pham, T. N. (2010). Higher education in Vietnam: reform, challenges and priorities. The Netherlands: Springer.

Ho Chi Minh Communist Youth Union. (2015). Ho Chi Minh Communist Youth Union. Retrieved from http://english.doanthanhnien.vn/

Horton, J., Macve, R., \& Struyven, G. (2004). Qualitative research: Experiences in using semi-structured interviews. In C. Humphrey \& B. Lee (Eds.), The real life guide to accounting research (pp. 339-357). Amsterdam, The Netherland: Elsevier Science.

Jones, A. (2010). Generic attributes in Accounting: The significance of the disciplinary context. Accounting Education, 19(1/2), 5-21. doi:10.1080/09639280902875523

Kalles, S., \& Ryan, T. G. (2015). Service-learning: Promise and possibility in post-secondary education. International Journal of Progressive Education, 11(1), 132-148.

Kearney, S., Perkins, T., \& Maakrun, J. (2014). A transformative experience: A short-term cross-cultural service-learning immersion to Kenya. Issues in Educational Research, 24(3), 229-237.

Kohlbacher, F. (2006). The use of qualitative content analysis in case study research. Retrieved from http://www.qualitative-research.net/index.php/fqs/article/view/75/154

Lau, H.-H., Hsu, H.-Y., Acosta, S., \& Hsu, T.-L. (2014). Impact of participation in extracurricular activities during college on graduate employability: An empirical study of graduates of Taiwanese business schools. Educational Studies (03055698), 40(1), 2647. doi:10.1080/03055698.2013.830244

Manpower Group. (2011). Building a high-skilled economy: A new Vietnam. Retrieved from http://projects.vef.gov/followupresearch/upload/BuildingAHigh-

SkilledEconomy_TheNewVietnam_A4.pdf

Merriam, S. B. (2009). Qualitative research: Aguide to design and implementation. San Francisco Jossey-Bass.

MOET. (2010). Công văn 2916/ BGDĐT-GDĐH hướng dẫn xây dựng và công bố chuẩn đầu ra ngành đào tạo. Hanoi: Ministry of Education and Training. Retrieved from http://thuvienphapluat.vn/cong-van/Giao-duc/Cong-van-2196-BGDDT-GDDH-cong-bochuan-dau-ra-nganh-dao-tao-104676.aspx.

O'Neill, G. (2009). A program wide approach to assessment: A reflection on some curriculum mapping tools. Paper presented at the AISHE 2009 Conference, Dublin, Ireland.

Retrived from

https://www.researchgate.net/profile/Geraldine_Oneill2/publication/265068839_A_progr amme-

wide_approach_to_assessment_a_reflection_on_some_curriculum_mapping_tools/links /53fde28b0cf2dca80003a39f.pdf

Osman, K. (2011). The inculcation of generic skills through service learning experience among science student teachers. Procedia - Social and Behavioral Sciences, 18(2011), 148-153. doi:10.1016/j.sbspro.2011.05.022

Pham, L. H., \& Fry, G. W. (2002). The emergence of private higher education in Vietnam: Challenges and opportunities. Educational Research for Policy and Practice, 1(1-2), 127-141. doi:10.1023/A:1021130320485

Pham, T. N. (2010). The higher education reform agenda: A vision for 2020. In G. Harman, M. Hayden, \& Pham Thanh Nghi (Eds.), Reforming higher education in Vietnam: Challenges and priorities (pp. 51-64). The Netherlands: Springer. 
Pitman, T., \& Broomhall, S. (2009). Australian universities, generic skills and lifelong learning. International Journal of Lifelong Education, 28(4), 439-458. doi:10.1080/02601370903031280

Scarinci, J., \& Pearce, P. (2012). The perceived influence of travel experiences on learning generic skills. Tourism Management, 33(2), 380-386. doi:10.1016/j.tourman.2011.04.007

Shattock, M. L. (2001). Impact of the Dearing Report on UK higher education. In D. Aspin, J. Chapman, M. Hatton, \& Y. Sawano (Eds.), International Handbook of Lifelong Learning (pp. 7-17). Dordrecht: Springer.

Shoenfelt, E. L., Stone, N. J., \& Kottke, J. L. (2013). Internships: An established mechanism for increasing employability. Industrial and Organizational Psychology, 6(1), 24-27. doi:10.1111/iops.12004

Stoner, G., \& Milner, M. (2010). Embedding generic employability skills in an accounting degree: Development and impediments. Accounting Education, 19(1-2), 123-138. doi:10.1080/09639280902888229

Tertiary Education Quality and Standards Agency. (2013). Australian qualifications framework. Australia: The Australian Qualifications Framework Council. Retrieved from http://www.aqf.edu.au/wp-content/uploads/2013/05/AQF-2nd-Edition-January-2013.pdf.

Thai Government. (2006). National qualifications framework for higher education in Thailand. Thailand.

The Association of Southeast Asian Nations. (2008). ASEAN Econmic Community Blueprint Jakarta, Indonesia.

Tran, N. C. (2009). Reaching out to society: Vietnamese universities in transition. Science \& Public Policy, 36(2), 91-95. doi:10.3152/030234209X413892

Tran, T. T. (2015). Is graduate employability the 'whole-of-higher-education-issue'? Journal of Education and Work, 28(3), 207-227. doi:10.1080/13639080.2014.900167

Tse, T. S. (2010). What do hospitality students find important about internships? Journal of Teaching in Travel \& Tourism, 10(3), 251-264. doi:10.1080/15313221003792027

Varghese, N. V. (2007). GATS and higher education: The need for regulatory policies. Retrieved from http://unesdoc.unesco.org/images/0015/001506/150689e.pdf

Vietnamese National Congress. (2012). Luật giáo dục đại học. Hanoi: Vietnamese National Congress. Retrieved from http://www.chinhphu.vn/portal/page/portal/chinhphu/hethongvanban?class_id=1\&mode= detail\&document_id=163054.

World Bank. (2008). Vietnam: Higher education and skills for growth. Retrieved from https://openknowledge.worldbank.org/handle/10986/7814

World Bank. (2017). Vietnam. Retrieved from: http://data.worldbank.org/country/vietnam

Yin, R. K. (2009). Case study research: Design and methods (4 ed.). Thousand Oaks, California: Sage. 